\title{
Role of Community in Leading Conservation: Effectiveness, Success and Challenges of Community-Based Anti-Poaching Unit in Nepal
}

\author{
Saroj Lamichhane ${ }^{1}$, Rajeev Joshi*2, ${ }^{\text {, }}$, Bishow Poudel ${ }^{3}$, Pramod Subedi ${ }^{4}$ \\ ${ }^{1}$ The School of Forestry and Natural Resource Management, IOF, Kritipur-44618, Nepal \\ ${ }^{2}$ Forest Research Institute (Deemed to be University), Dehradun, Uttarakhand-248195, India \\ ${ }^{3}$ Faculty of Forestry, Amity Global Education (Lord Buddha College), CTEVT, Kathmandu-44600, Nepal \\ ${ }^{4}$ Department of Science, Health and Technology, Natural Resource and Development, Nepal Open \\ University, Lalitpur-44700, Nepal \\ *Corresponding author: joshi.rajeev20@gmail.com | ORCID: https://orcid.org/0000-0003-1106-9911
}

How to cite this paper: Lamichhane, $S$., Joshi, R., Poudel, B. and Subedi, P. (2020).

Role of Community in Leading Conservation: Effectiveness, Success and Challenges of Community-Based AntiPoaching Unit in Nepal. Grassroots Journal of Natural Resources, 3(4): 94-109. Doi: https://doi.org/10.33002/nr2581.6853.03046

Received: 26 September 2020

Reviewed: 16 October 2020

Provisionally Accepted: 25 October 2020

Revised: 15 November 2020

Finally Accepted: 27 November 2020

Published: 20 December 2020

Copyright (๑) 2020 by author(s)

This work is licensed under the Creative Commons Attribution International License (CC BY 4.0). http://creativecommons.org/licenses/by/4.0/

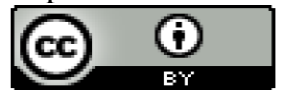

Open Access

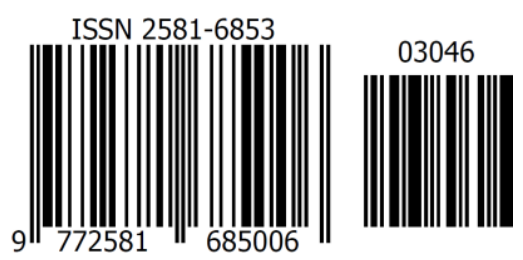

\begin{abstract}
Himalayan mountains have rich biodiversity and species endemism. Simultaneously, critical level of socioeconomic vulnerability and poverty presents significant potential for Community Based Conservation (CBC) practices aiming to provide both environmental and social benefits. Community based anti-poaching operation is poorly documented that hinders in assessing $\mathrm{CBC}$ practices in the field. To assess the effectiveness of Community Based Anti-Poaching Unit (CBAPU) in and around of Beeshazari lake of Chitwan National Park, Nepal, primary data was collected using semi-structured questionnaire, key informant interviews and focus group discussions. Unemployment and the consequent poverty were found as the key reason of poaching and other illegal activities. Patrolling, surveillance and information gathering against illegal activities, rescue of wildlife and awareness raising activities were the major activities of CBAPU, which has significantly contributed to wildlife conservation. Inadequate financial resource was found to be the greatest hindrance for anti-poaching operation in an organized and effective way.
\end{abstract}

Keywords

Biodiversity; Community based conservation; Illegal activities; Participation; Poaching; Chitwan National Park 


\section{Introduction}

Participatory conservation models including community-managed buffer zones and conservation areas (Bhattarai et al., 2017) have been common throughout developing countries. A top-down and state-centered approach to more decentralized management has been developed in the last three decades (Gibson and Marks, 1995; Hulme and Murphree, 2001). Community based conservation (CBC), the bottom-up participatory approach where maximum number of people are benefitted through the sustainable management and utilization of wildlife changing the rural people's behaviours and practices (Gibson and Marks, 1995), use the people and their new behaviours as a vehicle for achieving a conservation goal (Otto et al., 2013). However, the approach synthesizes on the idea that the communities will protect and conserve wildlife only if it is in their own (economic) interest to do so (Liebenberg and Grossman, 1994), integrating the rural development objectives with continuous biodiversity conservation and rural livelihood enhancement (Persha et al. 2011). It also provides the various other conservation strategies like payment for ecosystem services (PES) on which to build (Agrawal et al., 2008; Burgess et al., 2010) being driven by factors such as constrained resources for conservation, biodiversity loss, and burgeoning rural populations (Mariki, 2016; Roe et al., 2009).

The proponents of community-based wildlife management (CBWM) argue that devolving control of natural resources to local communities increases local participation, improves management of those resources, reduces conflicts, thereby improving the resource base and provision of benefits to communities (Bowler et al., 2014; Dressler et al., 2010; Suich, 2010). For achieving the success in conservation, increased patrol frequency should cover the maximum area of the national park by activating the anti-poaching units at grassroots level so as to strengthen the collaborative way of conservation ensuring the mechanism of benefit sharing (Mahatara et al., 2018). Against this background, Community Based Antipoaching Unit (CBAPU) is one of the initiatives of CBC at local level. In Nepal, CBAPU is a sub-unit of Buffer Zone User Committee (BZUC), which is a management committee of buffer zone (BZ) area. CBAPU is the unique community-based initiative (a voluntary association of user group members) dedicated for biodiversity conservation and curbing the illegal poaching, collection of fire and fuel wood in and around buffer zones (Songorwa, 1999). In CBAPU, involving people inclusively from different spectra of society will ensure motivation in conservation and discouragement of illegal activities (Poudyal, 2005). Currently, there are more than 600 CBAPUs consisting 5500 CBAPU members in Nepal (WWF, 2018). With the effective community based anti-poaching strategy, there was dramatic improvement in the successful Rhino conservation in Chitwan National Park (Mahatara et al., 2018).

Having virtue of a successful approach to curb the illegal activities, there is a greater need to assess its effectiveness, challenges and possibilities of replicating it to other parts on scale (Bhatta et al., 2018; TAL, 2006). Beeshazari Lake is part of Chitwan National Park (CNP), which embraces the buffer zones sharing the common boundary between people and wildlife. Thus, it acts as the easy and most viable area for the illegal trade of wildlife and wildlife products. Motivation of CBAPU in these areas can be prolific in reduction of illegal activities related to wildlife. Hence, investigations on the effectiveness of those units established in buffer zone and participation of diverse group of people in wildlife conservation was the primary focus of the study. It also includes cause and trend of poaching and illegal activities in CNP, activities of CBAPU as well as the 
success and challenges of CBAPU based on perception in and around Beeshazari lake of Chitwan National Park.

\section{Materials and Methods}

\section{Study Area}

The study was carried out in Beeshazari lake of Chitwan district, Nepal, which is an extensive oxbow lake system in the buffer zone of Chitwan National Park (CNP), a protected area in the inner Terai region of central Nepal. This wetland covers an area of 3,200 ha at an altitude of 286 masl and is situated between the Mahabharat mountain range to the North and the Siwalik range to the South. In August 2003, it has been designated as a Ramsar site. The globally threatened fauna like Bengal tiger (Panthera tigris), Great one-horned rhino (Rhinoceros unicornis), White-rumped vulture (Gyps bengalensis) and Gharial (Gavialis gangeticus) are the major animals found in the area. In total, 17 fish species are recorded in Beeshazari lake, including the threatened Puntius chola and the endemic Notopterus notopterus and Oxygaster bacaila. The site supports the largest number of Mugger crocodiles (Crocodylus palustris) (15-20 individuals). Total 273 bird species of 61 families are recorded, of which 60 are wetland species. Tikauli forest is an important corridor and refuge for wildlife migration from the Churia to the Mahabharat range. With the presence of these animals, illegal hunting, poaching, and trade of different wildlife parts occur in and around this lake (DNPWC, 2010).

The intensive study was conducted in buffer zone area of CNP in and around Beeshazari lake of Bharatpur Metropolitan city which includes 3 out of 22 Buffer Zone Areas i.e., Barandabhar Buffer Zone Area, Patihani Buffer Zone Area and Mirgakunja Buffer Zone Area where the CBAPU is operational and functioning (Figure 1). Barandabhar CBAPU, Patihani CBAPU and Mirgakunja CBAPU of respective buffer zone areas were sampled based on existence of CBAPU, their vulnerability to poaching and illegal activities, and their linkage to buffer zone area of CNP.

\section{Data Collection}

The primary data were collected through social survey methods involving participatory techniques such as on-site field observation, semi-structured household interview with CBAPU members, key informant interview (KII) and focus group discussions (FGD). Purposive sampling was adopted for the research with the sampling intensity of 30\%. Semi-structured interviews $(n=107$ out of 347 households) with member of CBPAUs were carried out to find the major causes of poaching, management activities of CBAPU, perception of people towards effectiveness of CBAPU and motivation factors for people's participation in CBAPU. Beside these, questions related to challenges and opportunities were also asked while interviewing the members of CBAPU.

To collect more information and to know the perception of different classes of society, a group of people involving females, marginalized, etc. was selected for FGD. Focus group discussion $(\mathrm{n}=5)$ was carried out with Mothers group (Aama samahu), Tharu community, dalit community for assessing people's perception related to motivation, opportunity, effectiveness, problems associated, and satisfaction. KII $(n=13)$ was conducted with CNP officials, teachers, local leaders and other stakeholders of national park asking about the facts and figures of cause of poaching, its trend, and effectiveness of CBAPUs. The activities of CBAPU were explored by discussing with 
the members of CBAPUs as well as interviewing key persons including chief wildlife warden of CNP.

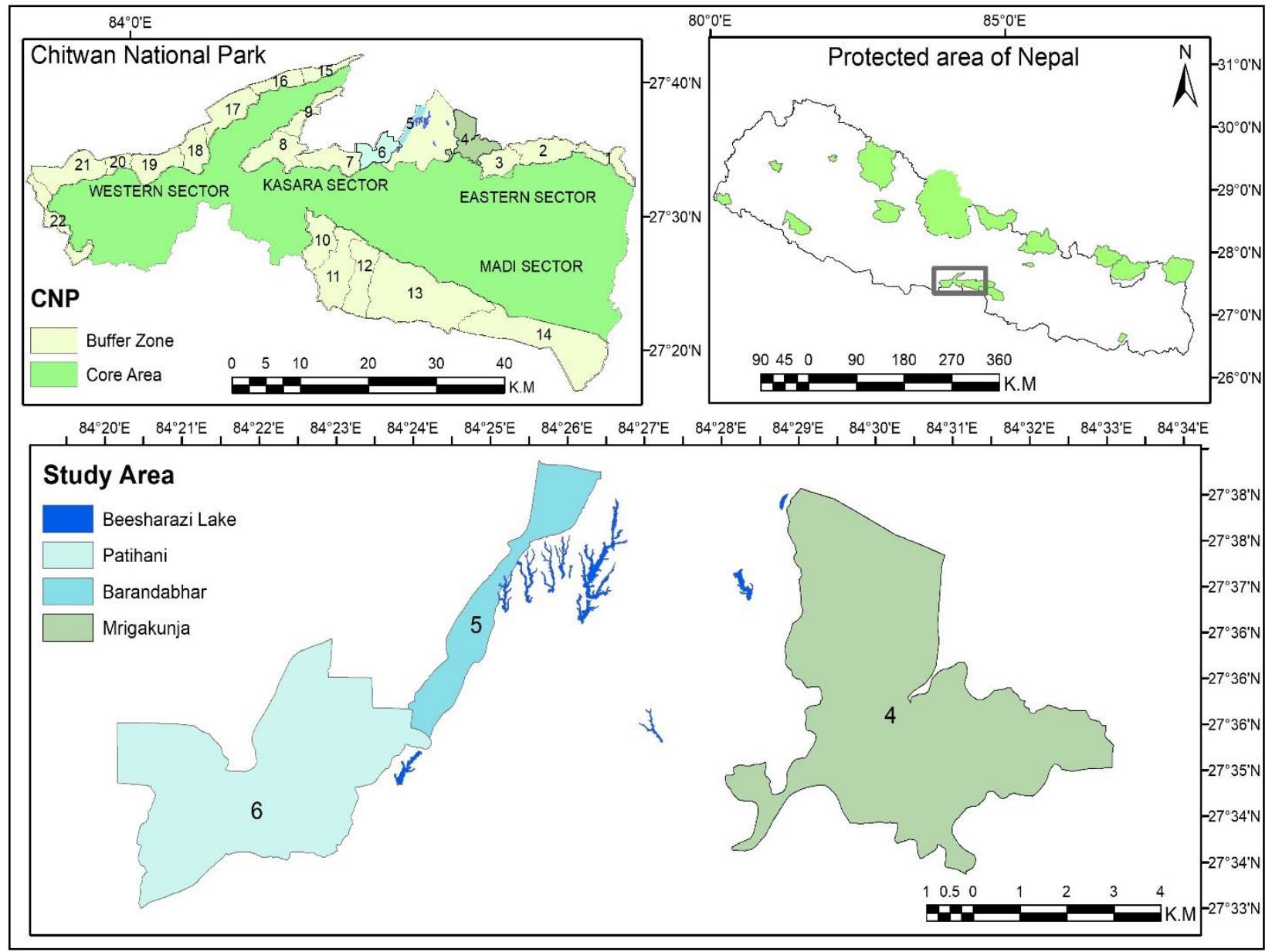

Figure 1: Map of CNP with BZ area including study area

Similarly, relevant and related secondary data were derived for finding trend of illegal activities and CBAPU activities from published journals, articles, newspapers, documents, annual reports, progress reports and other publications collected from office of Chitwan National Park (CNP), National Trust for Nature Conservation (NTNC), World Wide Fund for Nature (WWF), Department of National Park and Wildlife Conservation (DNPWC).

\section{Data Analysis}

Qualitative and quantitative data were analyzed with the help of SPSS and MS Excel 2010. The qualitative data was analyzed through descriptive mean, whereas quantitative data was analyzed through frequency distribution, mean and percentage. Non-parametric Friedman test was used for ranking different causes of poaching and mean rank was calculated. The perception of people was coded in point scale in Likert scale format. The mean scores (weighted mean) obtained from Likert scale was used to determine the perception. Chi-Square independent test was used to see the association in their perception of CBAPUs members on different aspect at 5\% level of significance. The result was presented in the form of tables, bar diagram, pie-chart and text. 


\section{Results}

\section{Socio-economic characteristics of respondents}

Out of 107 respondents interviewed during the study, $63.55 \%$ were males and $36.45 \%$ were females. However, to avoid gender bias, survey was based on the availability of household members during the field study, but still CBAPU was found dominated by males with low female participation. To obtain more reliable information, the household survey interview was performed with CBAPUs members having age between 20 to 60 years. The average age was 38, whereas maximum age was 56 and minimum age was 25. CBAPUs comprise members having middle age (36-55 yrs.) i.e., $54.21 \%$, followed by young age (20-35 years) i.e., $43.93 \%$, and old age (>55 years) i.e., 1.87\% (Table 1). This data shows that CBAPUs consist of people having varied age groups. About $48.60 \%$ of the respondents had a primary level education, while $25.23 \%$ had secondary level education, and $22.43 \%$ had a university level education. The remaining $3.74 \%$ were illiterate. Most of the CBAPU members were Brahmin/Chhetri caste. Out of the total respondents, $78.50 \%$ of the members were Brahmin/Chhetri, while $12.15 \%$ were Tharu and $5.6 \%$ of the members were dalit. Most of the community of the Chitwan district was inhabited by Brahmin and Chhetri, whereas another ethnical groups like Rana, Tharu, and other tribes occupy small area. Agriculture was the main source of livelihood for the CBAPUs members of Beeshazari lake. In this study, 50.47\% of the households (HHs) were dependent on agriculture, while $20.56 \% \mathrm{HHs}$ were engaged in government/private services and $18.69 \%$ were in business sectors. About $10.28 \%$ were involved in other occupations such as guides, security personals, etc.

Table 1: Socioeconomic characteristics of the respondents

\begin{tabular}{|c|c|c|}
\hline Category & Indicator & Percentage (\%) \\
\hline \multirow{3}{*}{ Gender } & Male & 63.55 \\
\cline { 2 - 3 } & Female & 36.45 \\
\hline \multirow{4}{*}{ Age group } & $20-35$ years & 43.93 \\
\cline { 2 - 3 } & $36-55$ years & 54.21 \\
\cline { 2 - 3 } & Above 55 years & 1.87 \\
\hline \multirow{4}{*}{ Education } & Primary & 48.6 \\
\cline { 2 - 3 } & Secondary & 25.23 \\
\cline { 2 - 3 } & University & 22.43 \\
\hline \multirow{5}{*}{ Ethnicity } & Illiterate & 3.74 \\
\cline { 2 - 3 } & Brahmin/Chhetri & 78.5 \\
\cline { 2 - 3 } & Tharu & 12.15 \\
\cline { 2 - 3 } & Dalit & 5.6 \\
\cline { 2 - 3 } & Others & 3.75 \\
\hline \multirow{5}{*}{ Occupation } & Agriculture & 50.47 \\
\cline { 2 - 3 } & Services & 20.56 \\
\cline { 2 - 3 } & Business & 18.69 \\
\cline { 2 - 3 } & Others & 10.28 \\
\hline
\end{tabular}




\section{Causes of poaching and other illegal activities in CNP}

Poaching and other illegal activities in and around protected area leads to the formation of CBAPU. Different socio-economic causes are responsible for illegal activities which were shown in table 2 with mean rank response of respondents.

Table 2: Mean rank response of respondents

\begin{tabular}{|c|c|c|}
\hline Causes & Mean Rank & \multirow{2}{*}{$\chi^{2}$ value } \\
\hline Unemployment $\#^{*}$ & 2.71 & \\
\hline Easy money $\#^{*}$ 13 $^{\wedge}$ & 3.28 & \\
\hline Low awareness $^{\wedge}$ & 4 & \\
\hline For livelihood $^{\wedge}$ & 4 \\
\hline Retaliation $^{\wedge}$ & 4.28 & \\
\hline Weak law enforcement $^{*}$ & 4.85 & \\
\hline Superstitious belief $^{\wedge}$ & 4.29 & \\
\hline
\end{tabular}

$(* p<0.05, \#$ : Economic factor, $\wedge$ : Social factor, $\infty$ : Legal factor $)$

Using non-parametric Friedman test, unemployment (mean rank $=2.71$ ) was observed as the major cause of poaching and illegal activities and causes were perceived significantly different by respondents.

\section{Trend of poaching and other illegal activities in CNP}

From fiscal year 2009-10 AD to 2018-19 AD, 655 registered cases of illegal activities (Figure 2) were registered by CNP office. Poaching, trade of wildlife parts, wood extraction, illegal fishing were main illegal activities recorded in CNP. There was fluctuation in incidences of poaching and wood extraction as well as other illegal activities. But during recent years, overall trend of these illegal activities was seen decreasing whereas poaching of all wildlife and illegal fishing were seen slightly oscillating. Poaching of mega animals like rhino, tiger and elephant fell to zero whereas poaching of small animals like deer, wild boar still exists.

\section{Activities of CBAPU}

\section{Information gathering \& surveillance}

Information about wildlife poachers, traders and suspected persons in and around buffer zone was provided to park authorities by CBAPUs. Beside these conflict incidences, wildlife death and rescue, encroachment information were also provided and coordinated with park authorities. Such activity helped in effective anti-poaching operation inside the park. The total area of CBAPU surveillance with the area of coverage is presented in the table 3. 


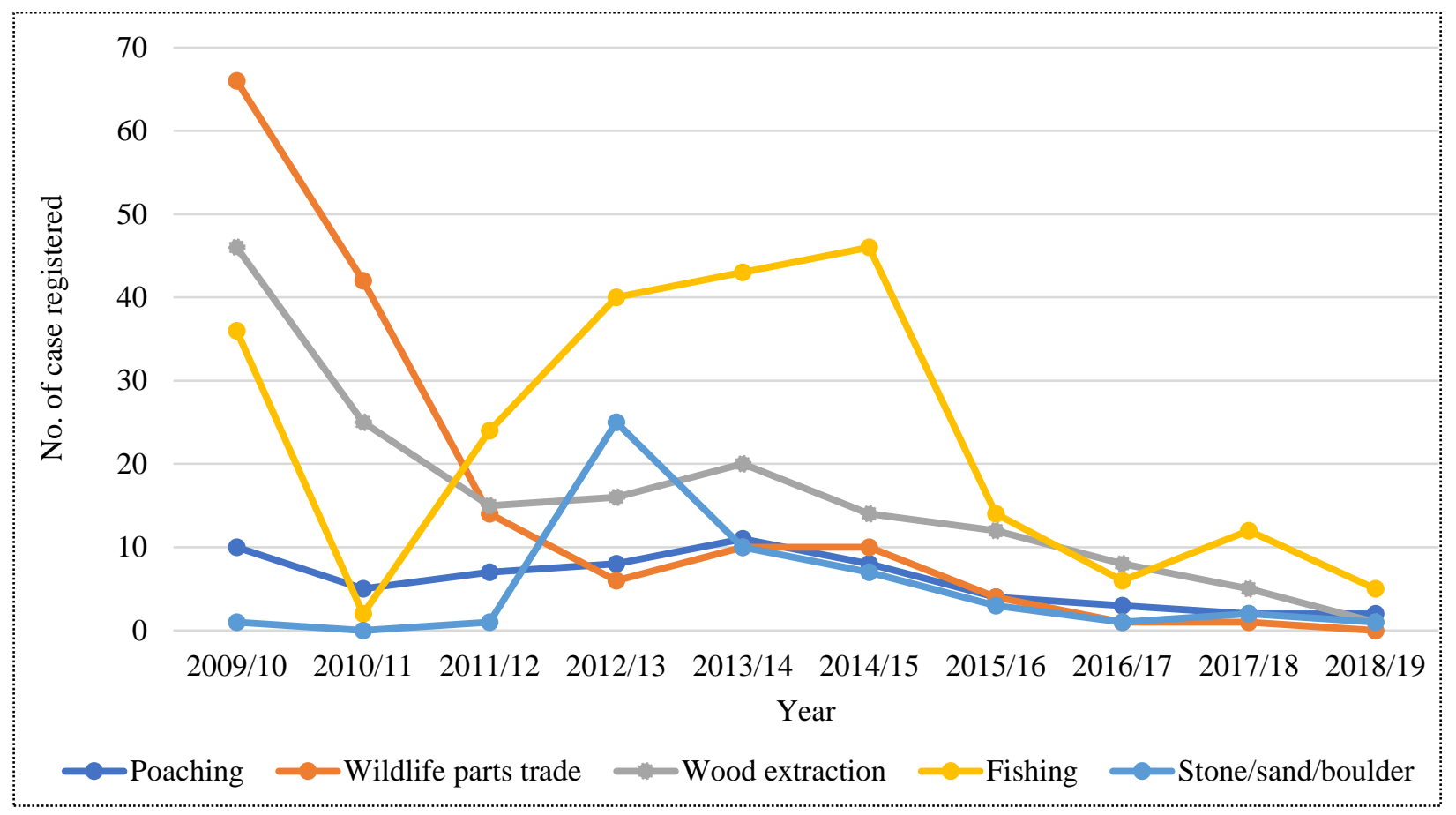

Figure 2: No. of poaching cases and illegal activities registered

Table 3: Area of Surveillance

\begin{tabular}{|l|l|l|}
\hline S.N. & Name of CBAPU & Area of Coverage $(\mathrm{sq} . \mathrm{km})$ \\
\hline 1. & Mirga Kunja & 26.29 \\
\hline 2. & Barandabahar & 4.16 \\
\hline 3. & Patihani & 16.75 \\
\hline
\end{tabular}

\section{Patrolling}

CBAPUs regularly patrol covering their buffer zone boundary to control illegal activities i.e., timber smuggling, poaching, forest area encroachment and illegal fishing (Table 4). Sometimes patrol occurs with Nepalese army/park staff using MIST (Management Information System), SMART (Spatial Monitoring and Reporting Tool) and real time tracking patrolling. Such activity creates motivation for members to conserve their environment.

Table 4: Intensity of CBAPUs patrolling

\begin{tabular}{|l|l|l|}
\hline Intensity of patrolling & Month & Remarks \\
\hline 1 day per week & June to August & Basically, River Patrol \\
\hline 1 day per week & September to February & Patrol around BZ \\
\hline 2 days per week & March to May & More intensity due to open forest \\
\hline
\end{tabular}

\section{Conservation based program}

In coordination with BZUC and CNP, CBAPU run various activities (Table 5) for creating awareness about various illegal activities, existing laws and policies, importance of biodiversity conservation, liable punishments for illegal works. 
Table 5: Activities promoting conservation-based program

\begin{tabular}{|c|c|c|}
\hline S. $N$. & Activities & Organizer \\
\hline 1 & Wetland cleanliness program & Mirga kunja CBAPU \\
\hline 2 & School awareness program & Patihani CBAPU \\
\hline 3 & School quiz competition & Mirga kunja CBAPU \\
\hline
\end{tabular}

\section{Rescue of wildlife animal}

Besides antipoaching operation, CBAPUs play vital role in wildlife rescue and treatment of wounded animals, as they handover such animals to park authorities for further action. During the study period, Mirga kunja CBAPU rescued Burmese python, deer, and birds as shown in table 6.

Table 6: Number of rescued wild animals by Mirga kunja CBAPU

\begin{tabular}{|c|c|}
\hline Fiscal Year & No. of rescued wildlife \\
\hline $2012 / 013$ & 3 \\
\hline $2013 / 014$ & 4 \\
\hline $2014 / 015$ & 1 \\
\hline
\end{tabular}

\section{Perception of people towards effectiveness of CBAPUs}

\section{Benefits received by the CBAPU members}

Local communities are a primary ally and stakeholder of conservation interventions like antipoaching. So, local people can participate in such conservation interventions only if they benefit from it. Table 7 shows the response of respondents about the benefits that they are deriving from being a member of CBAPUs. The majority of the respondents $(35.5 \%)$ indicated increased awareness and knowledge as the perceived benefit while lowest number of people $(5.1 \%)$ indicated rewards as the perceived benefit.

Table 7: Perception of benefits received by the CBAPUs members

\begin{tabular}{|c|l|c|}
\hline S. $N$. & \multicolumn{1}{|c|}{ Benefits } & Response \% $(N=107)$ \\
\hline 1 & Increased awareness & 35.5 \\
\hline 2 & Monitory & 8.3 \\
\hline 3 & Equipments and gears & 7.5 \\
\hline 4 & Social respect & 21.4 \\
\hline 5 & Self-satisfaction & 14.7 \\
\hline 6 & Capacity building trainings & 7.5 \\
\hline 7 & Rewards & 5.1 \\
\hline
\end{tabular}

\section{Success of CBAPU}

When the members were asked about their success, majority of the respondents $(32.1 \%)$ said that they were successful in raising awareness of local people, while a very few respondents (1.5\%) said that their achievement was seize of wildlife parts. 


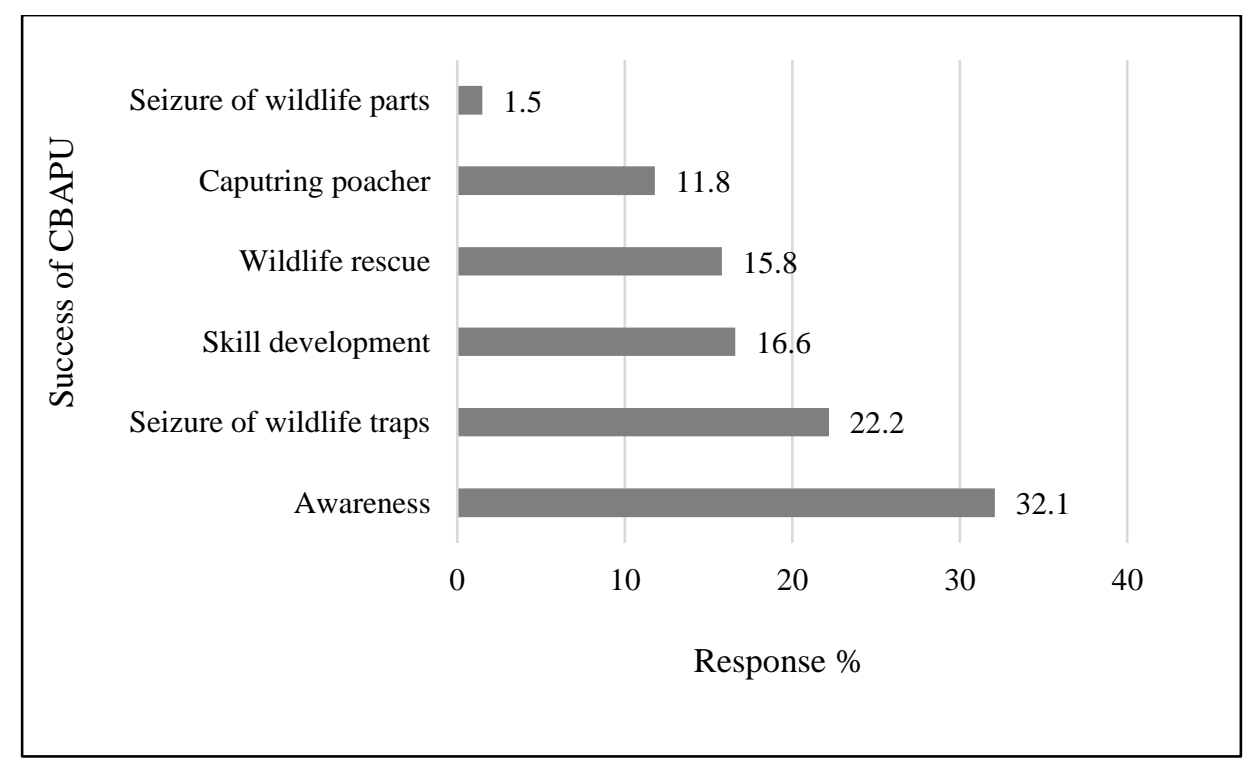

Figure 3: Success of CBAPUs

From the above data, we can say that CBAPUs are found to be effective especially in raising awareness and seizure of traps placed for wild animals as well as rescue of wildlife (Figure 3).

\section{Participation}

Regular meetings of CBAPUs are significant to make the members updated about their past activities and various operations and future plans. Though it was decided that regular meetings will be held every month, frequency of meeting was found to be irregular. Investigation of CBAPUs record book shows that $26.17 \%$ members have high level of participation in meetings, $58.88 \%$ have medium level of participation, and $14.95 \%$ have low level of participation in conservation meetings. When they were inquired about the cause for low level of attendance in meetings, majority of them indicated that lack of time was the main cause for not attending meetings. Overall, it can be said that there was medium level of participation of the members in CBAPUs meetings.

\section{Response on security assurance}

Security problem is seen as the main constraint for the effectiveness of CBAPUs. Regarding inquiry about security assurance, most of the respondents, i.e., $91.59 \%$, said that they did not feel secure while $8.41 \%$ respondents said that they felt secure while carrying anti-poaching activities. Members residing near the highway or in the urban area with decent security responded positive to the security threat.

\section{Financial condition of CBAPUs}

Fund is prerequisite to organize the conservation activities. Concerning inquiry regarding whether the CBAPUs have sufficient fund to carry out anti-poaching activities or not, most of the respondents $(90.65 \%)$ answered that their financial condition is weak i.e., they do not have sufficient fund, while $9.35 \%$ expressed that CBAPUs have sufficient fund to operate activities. Not 
all the people knew about financial management of CBAPU. Those who knew about it said their financial status was weak because there was still no sustainable source of income. When the respondents were asked about the strategy to cope with the financial problem, majority of the respondents, which constituted $72 \%$ of the total respondents, said that support from Government of Nepal and NGOs/INGOs can be the best strategy to cope with financial problem, while a few respondents $(7.5 \%)$ said that support from local leader can be the strategy to be financially stable.

Table 8: Strategy to cope with financial problem

\begin{tabular}{|c|l|c|}
\hline S.N. & \multicolumn{1}{|c|}{ Strategy to cope with financial problem } & Response \% \\
\hline 1. & Raising fund & 20.5 \\
\hline 2. & Support from GON and NGOs/INGOs & 72 \\
\hline 3. & Support from local leaders & 7.5 \\
\hline
\end{tabular}

\section{Assistance to CBAPUs}

When the members of CBAPUs were asked about the kind of assistance from GON and other agencies, majority of the respondents $(54.2 \%)$ said that they have been receiving financial assistance. A very few people (6.5\%) said that they have been supported with rewards and stuffs. From above data, we can say that majority of the respondents have been benefited by the financial assistance. However, some members were found unsatisfied with the financial support given to them, thus demotivated for the continuity of their job. Whereas some of the members were selfmotivated and dedicated to their task, and ready to continue their job regardless of rewards.

Table 9: Types of assistance to CBAPUs

\begin{tabular}{|c|l|c|}
\hline S.N. & \multicolumn{1}{|c|}{ Assistance } & Response \% \\
\hline 1 & Technical & 24.3 \\
\hline 2 & Financial & 54.2 \\
\hline 3 & Trainings/Tours & 15 \\
\hline 4 & Others (Rewards, Stuffs) & 6.5 \\
\hline
\end{tabular}

\section{Constraint of effective anti-poaching}

Every conservation activity has constraint that hinders the effective operation of it. Responses of respondents regarding different factors that obstruct the effective operation of anti-poaching were explored as shown in table 10.

Table 10: Constraints of effective antipoaching

\begin{tabular}{|c|l|c|}
\hline S.N. & \multicolumn{1}{|c|}{ Constraint of effective anti-poaching } & Response \% \\
\hline 1 & Lack of awareness & 22.2 \\
\hline 2 & Lack of resources & 8.6 \\
\hline 3 & Lack of coordination & 9.4 \\
\hline 4 & Livelihood problem & 54.6 \\
\hline 5 & Attitude & 5.2 \\
\hline
\end{tabular}


From the table 10, livelihood problem (54.6\%) was the main constraint that hinders the effective anti-poaching operation followed by lack of awareness on local community (22.2\%). It denotes constraint of effective anti-poaching operation in CNP.

\section{Ways to enhance effectiveness of CBAPU}

When the members of CBAPUs were inquired about the type of support that will enhance effectiveness of the unit, majority of the respondents (49.5\%) said financial support would enhance the effectiveness, while very few people $(1.9 \%)$ reported that insurance of members should be done (Figure 4). From the above data, it can be said that demand of majority of respondents was for financial support.

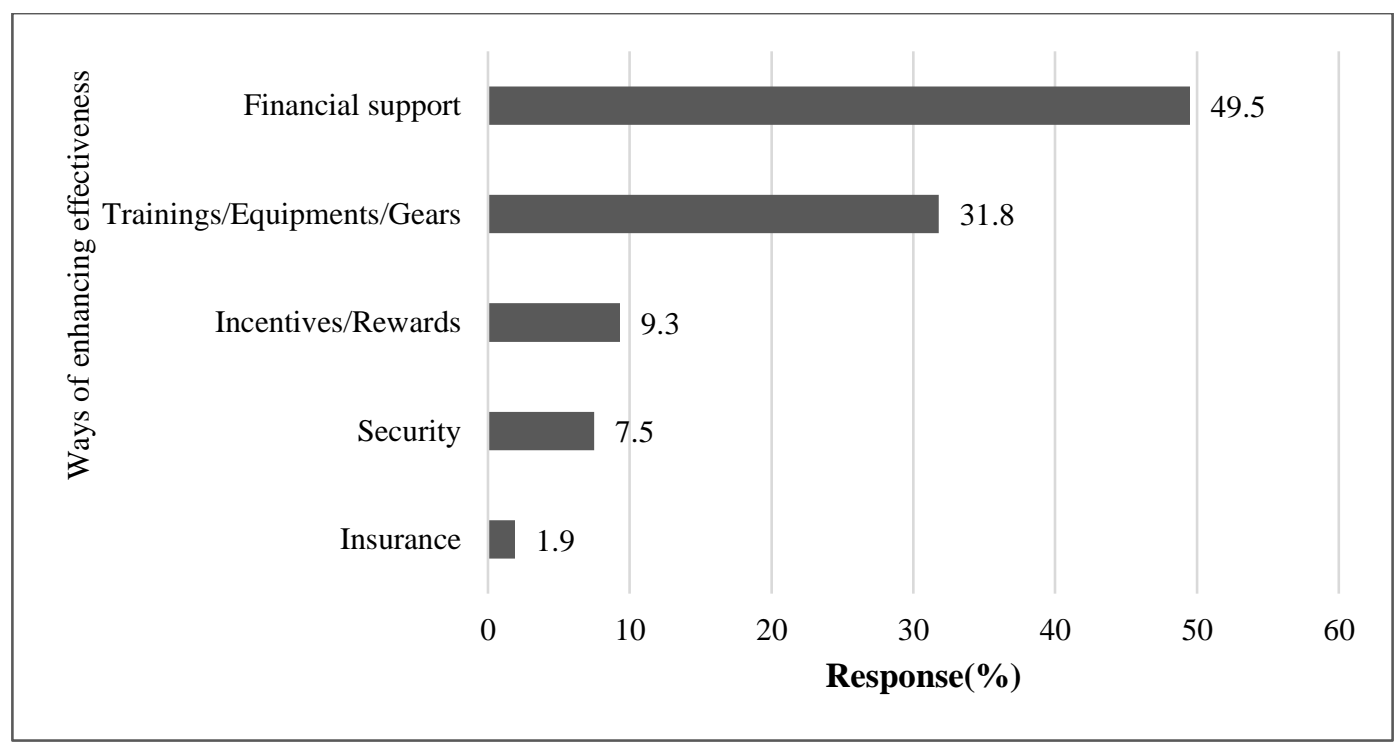

Figure 4: Ways to enhance effectiveness of CBAPU

\section{Perception on different aspects of $C B A P U$}

Respondents were asked to rate their level of agreement with statements about various aspects of CBAPU, using a series of Likert scales with ratings ranging from 1= "Agree" to 3= "Disagree". For the statement "Management actions of CBAPU are satisfactory" the weighted mean was 1.39 indicating that the respondents agreed to the statement. They are satisfied with current management action of CBAPU. The weighted mean for the statement "Women and marginalized groups should be motivated for active participation" was 1.28 indicating that the respondents agreed to the statement. For the statement "More CBAPU should be institutionalized in this area", the weighted mean was 1.94. This shows that the response on the given statement lean towards neutral. For the statement "Existing networking system of CBAPU is adequate" the weighted mean was 2.41 indicating that the respondents were neutral to the statement. They are not very much satisfied with current mechanism of CBAPU.

The weighted mean for the statement, "CBAPU is receiving adequate help and assistance from external agencies", was 2.61, and the statement "Incentive received for CBAPU work is 
satisfactory", was 2.55 indicating that the overall responses of the respondents lean towards disagreement. They are not satisfied with the support being provided to them.

Table 11: Perception on different aspects of CBAPUs

\begin{tabular}{|c|c|c|c|c|c|c|}
\hline \multirow[b]{2}{*}{ S.N. } & \multirow[b]{2}{*}{ Statements } & \multicolumn{3}{|c|}{ Response (\%) } & \multirow{2}{*}{$\begin{array}{l}\text { Weighted } \\
\text { Mean }\end{array}$} & \multirow[b]{2}{*}{$\chi^{2}$ value } \\
\hline & & $\begin{array}{l}\text { Agree } \\
\text { (1) }\end{array}$ & $\begin{array}{l}\text { Neutral } \\
\text { (2) }\end{array}$ & $\begin{array}{l}\text { Disagree } \\
\text { (3) }\end{array}$ & & \\
\hline 1 & $\begin{array}{l}\text { Management actions of } \\
\text { CBAPU are satisfactory }\end{array}$ & 70.1 & 20.6 & 9.3 & 1.39 & $67.084 *$ \\
\hline 2 & $\begin{array}{l}\text { CBAPU is able to give result } \\
\text { in wildlife conservation }\end{array}$ & 71 & 20.6 & 8.4 & 1.37 & $70.785^{*}$ \\
\hline 3 & $\begin{array}{l}\text { CBAPU play vital role in } \\
\text { controlling poaching and } \\
\text { other illegal activities }\end{array}$ & 74.8 & 15.9 & 9.3 & 1.35 & $83.346^{*}$ \\
\hline 4 & $\begin{array}{l}\text { CBAPU is receiving adequate } \\
\text { help and assistance }\end{array}$ & 8.4 & 22.4 & 69.2 & 2.61 & $64.953^{*}$ \\
\hline 5 & $\begin{array}{l}\text { More CBAPUs should be } \\
\text { institutionalized in this area }\end{array}$ & 15 & 75.7 & 9.3 & 1.94 & $86.935^{*}$ \\
\hline 6 & $\begin{array}{l}\text { CBAPU should work jointly } \\
\text { with army/park staffs }\end{array}$ & 58.9 & 33.6 & 7.5 & 1.49 & $42.411 *$ \\
\hline 7 & $\begin{array}{l}\text { Women and marginalized } \\
\text { group should be motivated for } \\
\text { active participation }\end{array}$ & 80.4 & 11.2 & 8.4 & 1.28 & $106.673^{*}$ \\
\hline 8 & $\begin{array}{l}\text { Existing networking system is } \\
\text { adequate }\end{array}$ & 10.3 & 38.3 & 51.4 & 2.41 & $28.336 *$ \\
\hline 9 & $\begin{array}{l}\text { Major problem in CBAPU } \\
\text { member is fear and insecure }\end{array}$ & 57.9 & 29 & 13.1 & 1.55 & $33.215^{*}$ \\
\hline 10 & $\begin{array}{l}\text { Incentive received for } \\
\text { CBAPU work is satisfactory }\end{array}$ & 10.3 & 26.2 & 63.6 & 2.55 & $48.019 *$ \\
\hline 11 & $\begin{array}{l}\text { Overall activities performed } \\
\text { by CBAPU are adequate }\end{array}$ & 29.9 & 60.7 & 9.3 & 1.79 & $42.019 *$ \\
\hline 12 & $\begin{array}{l}\text { Overall activities of CBAPU } \\
\text { are satisfactory }\end{array}$ & 68.2 & 20.6 & 11.2 & 1.43 & $60.019 *$ \\
\hline
\end{tabular}

$*(P<0.05)=$ Statement is perceived significantly different by respondents.

\section{Discussion}

Poaching is one of the serious threats for survival of wild animals. Understanding the causes of poaching is difficult when the hunter and hunting are unclear and to know the factors that accelerate or deter poaching is necessary for effective management (Shivik, 2006). A range of socioeconomic factors (Table 2) were responsible for illegal activities in which unemployment was the major cause of poaching and illegal activities in and around CNP. Shrestha (2009) explored low awareness was the main cause in Bardia National Park (BNP) whereas Bhatta and Joshi (2020) explored unemployment was the main cause of poaching in Shuklaphanta National Park (SNP), which supports findings of this study. CBAPUs have played significant role in raising awareness 
of local people, while unemployment remains unaffected and was a major cause prevalent for poaching. Paudel et al. (2020) indicated that poverty was driving force for illegal wildlife trade in Nepal that supports findings of this study.

Recognizing local communities' role in conservation intervention is crucial in anti-poaching and combating illegal activities. Overall trend of illegal activities (Figure 2) was seen decreasing in CNP because CBAPUs in coordination with park authorities have played vital role in the exploration of illegal activities. Mainly the border area was observed as the prominent area of wildlife trade. Open border with India is seen as the main constraint in controlling illegal trade. Increasing the ability and motivation of anti-poaching staff and associated communities to protect wildlife is a key step towards achieving zero poaching of rhino. As a result, Nepal was successful in celebrating zero poaching year of rhino on five occasions i.e., in 2011, 2013, 2015, 2016, 2018 (WWF, 2018). For this achievement, youth led CBAPU was one of the tool kits for antipoaching operation (CNP, 2017).

CBAPUs mainly established for anti-poaching operation but working area are broad and encompass wide range of activities. To fight against poaching, CNP has been extensively mobilizing local level buffer zone institutions and the local user committees are proactively working in anti-poaching operations. The youth led CBAPUs form wildlife watch groups in range posts to keep vigilance on poachers and suspects, gather information on illicit activities, inform concerned authorities and control wildlife crimes. In doing so, the tiger and rhino conservation coordination committees are mobilized to lead on-the-ground efforts to curb crime against biodiversity, including poaching and illegal wildlife trade. Through these patrolling efforts, illegal timber has been confiscated, prey species rescued, and illegal quarrying of sand and boulders has been significantly reduced in the national park (CNP, 2017).

Local people's participation is key for the conservation activities at grassroots level. However, in the study area, there was inadequate level of local people participation during the formation of CBAPUs. This is due to less time for conservation activities, low direct benefits, and low security assurance. Low security assurance for the CBAPU members at SNP was found to be deterrent for the effective anti-poaching operation (Bhatta et al., 2018). Rokaya (2009) revealed that a threat from poachers was one of the factors that led to the dissatisfaction of CBAPU members of SNP. Similarly, Shrestha (2009) also revealed that low security assurance to CBAPU members was the factor that clues to the decreased level of participation of local people in BNP. Above mentioned studies are in line to the findings of this study.

The result of this study shows that maximum number of respondents responded that the financial condition of CBAPU was weak as they do not have any sustainable income source due to inadequate proper coordination and documentation within park office and NGOs/INGOs. It is creating the problem for sustainability. As Wildlife Times (2011) illustrated that the main challenge for CBAPU is self-sustenance, it does not have enough resources. Similarly, Rokaya (2009) revealed that CBAPUs are working efficiently in SNP, but they are facing financial problem. The greatest problem for anti-poaching operations in case of Nepal seems to be the lack of adequate funding for the intelligence gathering networks, which is very effectual against poaching (Thapa, 2016). So, dearth of financial assets has been one of the constraints to CBAPU for carrying out its activities in the fullest (Table $8 \& 9$ ). 
People did not have sufficient time to spend on conservation activities as they must work hard to sustain their life. The finding showed livelihood problem (Table 10) as the major constraint for effective anti-poaching operation. Thapa (2016) indicated poverty remains at the root cause of poaching in Chitwan. Rokaya (2009) revealed that lack of awareness, lack of coordination and political aspect as the constraints of effective anti-poaching operation in SNP. This suggests livelihood support programs from park authorities as well as external agencies require motivating the local people for conservation.

CBAPUs can be the best solution for anti-poaching at local level. For that, CBAPUs should be enhanced through financial support with capacity building training and field gears (Figure 4). Similarly, institutional development and capacity building, financial support as well as strengthening of security means of members, reward system, sufficient trainings and joint patrolling with army can be best way to make CBAPU more effective (Rokaya, 2009; Shrestha, 2009; Bhatta et al., 2018; Subedi et al., 2020).

\section{Conclusion}

Initiation of anti-poaching units has lowered the trend of poaching and illegal activities, but not much effective as it should be. As with changing context, poachers may get used to know about anti-poaching patrols and adopt effective combat strategies. This requires integrated and wellcoordinated anti-poaching activities and other suitable conservation interventions. Awareness programme with well collaboration with local people is always a necessity for making them conscious about biodiversity conservation and its importance. Strong institutional arrangements with favorable policy, well coordination between government agencies and conservation partners including local communities is key to success. Replication of CBAPU outside the protected area with broader activities is required including conflict mitigation for addressing increased human wildlife conflicts. Capacity building trainings, skill-based trainings to pursue income generation activities, financial support, security assurance with insurance of members and equipment and field gears for anti-poaching operation are required for sustainability of CBAPUs in Nepal.

\section{Acknowledgements}

The authors greatly acknowledge Narayan Prasad Gautam, Asish Gurung, Parbesh Adhikari, Bhuwan Singh Bista and Prasant Ghimire for the generous support during this research. Authors would like to thank DNPWC for providing the permission, and NTNC-BCC, Sauraha, Chitwan for providing financial support to conduct the research.

\section{References}

Agrawal, A., Chhatre, A. and Hardin, R. (2008). Changing governance of the world's forests. Science, 320(5882): 1460-1462. Doi: http://doi.org/10.1126/science.1155369

Bhatta, K.P., Bhattarai, S. and Aryal, A. (2018). Community Based Anti-Poaching Operation: Effective Model for Wildlife Conservation in Nepal. Journal of Poultry, Fisheries and Wildlife Sciences, 6(195): 2. Doi: http://doi.org/10.4172/2375-446X.1000195

Bhatta, M. and Joshi, R. (2020). Analysis of Human Wildlife Conflict in Buffer Zone: A Case Study of Shuklaphanta National Park, Nepal. Grassroots Journal of Natural Resources, 3(3): 28-45. Doi: https://doi.org/10.33002/nr2581.6853.03033 
Bhattarai, B. R., Wright, W., Poudel, B. S., Aryal, A., Yadav, B. P. and Wagle, R. (2017). Shifting paradigms for Nepal's protected areas: history, challenges and relationships. Journal of Mountain Science, 14(5): 964-979. Doi: http://doi.org/10.1007/s11629-016-3980-9

Bowler, D.E., Buyung-Ali, L.M., Healey, J.R., Jones, J.P., Knight, T.M. and Pullin, A.S. (2012). Does community forest management provide global environmental benefits and improve local welfare? Frontiers in Ecology and the Environment, 10(1): 29-36. Doi: http://doi.org/10.1890/110040

Burgess, N.D., Bahane, B., Clairs, T., Danielsen, F., Dalsgaard, S., Funder, M. and Kilahama, F. (2010). Getting ready for REDD $^{+}$in Tanzania: a case study of progress and challenges. Oryx, 44(3): 339-351. DOI: https://doi.org/10.1017/S0030605310000554

CNP (2017). Zero poaching report final: A newsletter dated November 26, 2017. Chitwan National Park, Nepal. http://www.chitwannationalpark.gov.np/index.php/zero-poaching-year

DNPWC. 2010. Annual Report 2009-2010. Ministry of Forest and Soil Conservation, Kathmandu, Nepal.

Dressler, W., Büscher, B., Schoon, M., Brockington, D.A.N., Hayes, T., Kull, C.A., McCarthy J. and Shrestha, K. (2010). From hope to crisis and back again? A critical history of the global CBNRM narrative. Environmental Conservation, 37(01): 5-15. Doi: http://doi.org/10.1017/S0376892910000044

Gibson, C.C. and Marks, S.A. (1995). Transforming rural hunters into conservationists: an assessment of community-based wildlife management programs in Africa. World Development, 23(6): 941-957. Doi: http://doi.org/10.1016/0305-750X(95)00025-8

Hulme, D. and Murphree, M. (2001). African wildlife and livelihoods: The promise and performance of community conservation. Suffolk: James Currey Ltd. (Boydell \& Brewer).

Liebenberg, L. and Grossman, D. (1994). Towards a new nature conservation policy Discussion document prepared for the Land and Agriculture Policy Centre (LAPC), Durban, South Africa.

Mahatara, D., Rayamajhi, S. and Khanal, G. (2018). Impact of anti-poaching approaches for the success of Rhino conservation in Chitwan National Park, Nepal. Banko Janakari, 28(2): 23-31. Doi: http://doi.org/10.3126/banko.v28i2.24185

Mariki, S.B. (2016). Social impacts of protected areas on gender in West Kilimanjaro, Tanzania. Open Journal of Social Sciences, 4(03): $220 . \quad$ Doi: http://doi.org/10.4236/jss.2016.43028

Otto, J., Zerner, C., Robinson, J., Donovan, R., Lavelle, M., Villarreal, R. and Pearl, M. (2013). Natural connections: perspectives in community-based conservation. Washington, DC: Island Press.

Persha, L., Agrawal, A. and Chhatre, A. (2011). Social and ecological synergy: local rulemaking, forest livelihoods, and biodiversity conservation. Science, 331(6024): 1606-1608. Doi: 10.1126/science. 1199343

Paudel, K., Potter, G.R. and Phelps, J. (2020). Conservation enforcement: Insights from people incarcerated for wildlife crimes in Nepal. Conservation Science and Practice, 2(2): e137. Doi: http://doi.org/10.1111/csp2.137

Poudyal, M. (2005). A study of the reasons for an increase in poaching of the one-horned Indian rhinoceros in Chitwan National Park, Nepal (Doctoral dissertation, School of Resource and Environmental Management-Simon Fraser University).

Roe, D., Nelson, F. and Sandbrook, C. (Eds.). (2009). Community management of natural resources in Africa: Impacts, experiences and future directions (No. 18). London: IIED. 
Rokaya P.B. (2009). Effectiveness of Community Based Anti- poaching operation in Biodiversity conservation. A case study from Shuklaphanta Wildlife Reserve, Kanchanpur, Nepal.

Shivik, J.A. (2006). Tools for the edge: what's new for conserving carnivores? Bio Science, 56: 253-259.

Shrestha, P.S. (2009). An Assessment on Effectiveness of Community Based Anti-Poaching Operation in Langtang National Park, B.Sc. Forestry Research Thesis submitted to Tribhuvan University, Institute of Forestry, Pokhara, Nepal.

Songorwa, A.N. (1999). Community-based wildlife management (CWM) in Tanzania: are the communities interested? World Development, 27(12): 2061-2079. Doi: http://doi.org/10.1016/S0305-750X(99)00103-5

Subedi, P., Joshi, R., Poudel, B. and Lamichhane, S. (2020). Status of Human-Wildlife conflict and Assessment of Crop Damage by Wild Animals in Buffer Zone Area of Banke National Park, Nepal. Asian Journal of Conservation Biology, 9(2): 196-206.

Suich, H. (2010). The livelihood impacts of the Namibian community based natural resource management programme: a meta-synthesis. Environmental Conservation, 37(1): 45-53. Doi: https://doi.org/10.1017/S0376892910000202

TAL (Terai Arc Landscape) (2006). Anti-poaching: A newsletter dated October 26, 2006.

Thapa, R. (2016). Poaching Statistics of Rhinoceros Unicornis In Chitwan National Park, Nepal: A Review. International Journal of Applied and Natural Sciences, 5(3): 29-34.

Wildlife Times (2011). Community Based Anti-poaching measures. Wildlife Times, 5(30).

WWF (2018). Nepal's Zero Poaching Standard: A newsletter dated October 2, 2018. http://wwf.panda.org/knowledge_hub/all_publications/?335795/Nepals-Zero-PoachingStandard 